\title{
Editorial
}

\section{Diets, Foods and Food Components' Effect on Dyslipidemia}

\author{
Federica Fogacci $1,2,3, * \mathbb{D}$, Claudio Borghi $1,2 \mathbb{C}$ and Arrigo F. G. Cicero ${ }^{1,2,3} \mathbb{D}$ \\ 1 Medical and Surgical Science Department, University of Bologna, 40138 Bologna, Italy; \\ claudio.borghi@unibo.it (C.B.); arrigo.cicero@unibo.it (A.F.G.C.) \\ 2 IRCCS Azienda Ospedaliero, Universitaria di Bologna, 40138 Bologna, Italy \\ 3 Italian Nutraceutical Society (SINut), 40138 Bologna, Italy \\ * Correspondence: federica.fogacci@studio.unibo.it
}

Citation: Fogacci, F.; Borghi, C.; Cicero, A.F.G. Diets, Foods and Food Components' Effect on Dyslipidemia. Nutrients 2021, 13, 741. https:// doi.org/10.3390/nu13030741

Received: 22 February 2021

Accepted: 25 February 2021

Published: 26 February 2021

Publisher's Note: MDPI stays neutral with regard to jurisdictional claims in published maps and institutional affiliations.

Copyright: (c) 2021 by the authors. Licensee MDPI, Basel, Switzerland. This article is an open access article distributed under the terms and conditions of the Creative Commons Attribution (CC BY) license (https:/ / creativecommons.org/licenses/by/ $4.0 /)$.
Hypercholesterolemia is a well-known independent risk factor for cardiovascular disease and a recognized target of pharmacological therapeutic agents in both primary and secondary prevention [1]. There is increasing interest in the use of natural lipid-lowering compounds that may delay or circumvent drug therapy. These compounds could be included as part of a diet pattern, as single foods or as food components transformed into dietary supplements [2].

To date, there is a strong evidence showing that dietary factors are able to influence atherogenesis. In particular, the Mediterranean diet is particularly rich in active vegetable compounds, contributing to its positive effect on human health [3]. However, other active compounds could be isolated and concentrated from non-nutrient vegetable sources, such as medicinal plants [4]. Finally, natural dietary and non-dietary lipid-lowering compound could have pleiotropic effect on lipids and on other cardiovascular risk factors, for instance increasing the cholesterol resistance to oxidative stress, reducing microinflammation, improving the endothelial health, etc. [5].

Based on this background, the volume entitled "Diets, Foods and Food Components" Effect on Dyslipidemia" samples the contributions of a number of recognized experts in the field.

An interesting review summarizes the number of natural compounds reducing the plasma level of Proprotein convertase subtilisin/kexin type 9 (PCSK9), a key enzyme in the metabolism of LDL-cholesterol receptors on the liver cell surface [6].

Trautwein and McKay reviewed the effect of plant-based diet on dyslipidemia and cardiovascular risk [7]. Carresi et al. considered the potential effect of bergamot polyphenolic fraction on the prevention of metabolic syndrome [8] and Santos et al. critically appraised the efficacy of plant-derived omega-3 polyunsaturated fatty acids from foodstuffs and supplements upon lipid profile and several cardiometabolic markers [9].

A range of preclinical evidence highlights the antiobesity effect of Chrysanthemum morifolium [10], the antioxidant effect of red propolis [11], the cholesterol-lowering and hepatoprotective effects of black raspberry [12], the effect of blackcurrant in preventing dyslipidemia and hepatic steatosis [13], the antioxidant activity of polyphenon-60 from green tea in chitosan microspheres [14], and the combined effect of omega-3 fatty acids and glibenclamide on abnormal lipid profile, increased blood glucose and impaired liver and kidney functions [15].

New epidemiological evidence supports a link between different dietary patterns [16], charbohydrate intake [17], fructose intake [18], vitamin B12 serum levels [19] and lipid profile and other markers of cardiovascular disease risk. Findings from the randomized clinical trials included in the Special Issue support the use of new nutraceutical formulations with lipid-lowering effects. The BELT (Beta-glucan Effects on Lipid profile, glycemia and inTestinal health) study evaluated the medium-term effects of dietary supplementation with oat fibers in a sample of healthy subjects [20], and the NATCOL (NutrAceuTical COmbination on Low-density lipoprotein cholesterol) study tested the effect of dietary 
supplementation with Levelip Duo ${ }^{\circledR}$ on low-density lipoprotein cholesterol concentrations and lipid profile in subjects with suboptimal blood cholesterol levels [21]. Finally, a systematic review and meta-analysis of randomized controlled clinical studies included in the Special Issue supports the use of Armolipid Plus ${ }^{\circledR}$ in clinical practice [22].

In this context, the volume is a source of new knowledge on the effect of diets, foods and food components on dyslipidemia.

Funding: This research received no external funding.

Conflicts of Interest: The authors declare no conflict of interest.

\section{References}

1. Cicero, A.; Landolfo, M.; Ventura, F.; Borghi, C. Current pharmacotherapeutic options for primary dyslipidemia in adults. Expert Opin. Pharm. 2019, 20, 1277-1288. [CrossRef]

2. Cicero, A.F.G.; Fogacci, F.; Zambon, A. Red Yeast Rice for Hypercholesterolemia: JACC Focus Seminar. J. Am. Coll. Cardiol. 2021, 77, 620-628. [CrossRef]

3. Zhubi-Bakija, F.; Bajraktari, G.; Bytyçi, I.; Mikhailidis, D.P.; Henein, M.Y.; Latkovskis, G.; Rexhaj, Z.; Zhubi, E.; Banach, M.; International Lipid Expert Panel (ILEP). The impact of type of dietary protein, animal versus vegetable, in modifying cardiometabolic risk factors: A position paper from the International Lipid Expert Panel (ILEP). Clin. Nutr. 2021, 40, 255-276. [CrossRef]

4. Poli, A.; Barbagallo, C.M.; Cicero, A.; Corsini, A.; Manzato, E.; Trimarco, B.; Bernini, F.; Visioli, F.; Bianchi, A.; Canzone, G.; et al. Nutraceuticals and functional foods for the control of plasma cholesterol levels. An intersociety position paper. Pharm. Res. 2018, 134, 51-60. [CrossRef]

5. Cicero, A.; Colletti, A.; Bajraktari, G.; Descamps, O.; Djuric, D.M.; Ezhov, M.; Fras, Z.; Katsiki, N.; Langlois, M.; Latkovskis, G.; et al. Lipid-lowering nutraceuticals in clinical practice: Position paper from an International Lipid Expert Panel. Nutr. Rev. 2017, 75, 731-767. [CrossRef] [PubMed]

6. Adorni, M.P.; Zimetti, F.; Lupo, M.G.; Ruscica, M.; Ferri, N. Naturally Occurring PCSK9 Inhibitors. Nutrients 2020, $12,1440$. [CrossRef]

7. Trautwein, E.A.; McKay, S. The Role of Specific Components of a Plant-Based Diet in Management of Dyslipidemia and the Impact on Cardiovascular Risk. Nutrients 2020, 12, 2671. [CrossRef]

8. Carresi, C.; Gliozzi, M.; Musolino, V.; Scicchitano, M.; Scarano, F.; Bosco, F.; Nucera, S.; Maiuolo, J.; Macrì, R.; Ruga, S.; et al. The Effect of Natural Antioxidants in the Development of Metabolic Syndrome: Focus on Bergamot Polyphenolic Fraction. Nutrients 2020, 12, 1504. [CrossRef]

9. Santos, H.O.; Price, J.C.; Bueno, A.A. Beyond Fish Oil Supplementation: The Effects of Alternative Plant Sources of Omega-3 Polyunsaturated Fatty Acids upon Lipid Indexes and Cardiometabolic Biomarkers-An Overview. Nutrients 2020, 12, 3159. [CrossRef] [PubMed]

10. Shon, J.C.; Kim, W.C.; Ryu, R.; Wu, Z.; Seo, J.-S.; Choi, M.-S.; Liu, K.-H. Plasma Lipidomics Reveals Insights into Anti-Obesity Effect of Chrysanthemum morifolium Ramat Leaves and Its Constituent Luteolin in High-Fat Diet-Induced Dyslipidemic Mice. Nutrients 2020, 12, 2973. [CrossRef] [PubMed]

11. Mendonça, M.A.A.d.; Ribeiro, A.R.S.; Lima, A.K.d.; Bezerra, G.B.; Pinheiro, M.S.; Albuquerque-Júnior, R.L.C.d.; Gomes, M.Z.; Padilha, F.F.; Thomazzi, S.M.; Novellino, E.; et al. Red Propolis and Its Dyslipidemic Regulator Formononetin: Evaluation of Antioxidant Activity and Gastroprotective Effects in Rat Model of Gastric Ulcer. Nutrients 2020, 12, 2951. [CrossRef]

12. Lim, T.; Ryu, J.; Lee, K.; Park, S.Y.; Hwang, K.T. Protective Effects of Black Raspberry (Rubus occidentalis) Extract against Hypercholesterolemia and Hepatic Inflammation in Rats Fed High-Fat and High-Choline Diets. Nutrients 2020, $12,2448$. [CrossRef] [PubMed]

13. Nanashima, N.; Horie, K.; Yamanouchi, K.; Tomisawa, T.; Kitajima, M.; Oey, I.; Maeda, H. Blackcurrant (Ribes nigrum) Extract Prevents Dyslipidemia and Hepatic Steatosis in Ovariectomized Rats. Nutrients 2020, 12, 1541. [CrossRef] [PubMed]

14. Souto, E.B.; da Ana, R.; Souto, S.B.; Zielińska, A.; Marques, C.; Andrade, L.N.; Horbańczuk, O.K.; Atanasov, A.G.; Lucarini, M.; Durazzo, A.; et al. In Vitro Characterization, Modelling, and Antioxidant Properties of Polyphenon-60 from Green Tea in Eudragit S100-2 Chitosan Microspheres. Nutrients 2020, 12, 967. [CrossRef] [PubMed]

15. Khadke, S.; Mandave, P.; Kuvalekar, A.; Pandit, V.; Karandikar, M.; Mantri, N. Synergistic Effect of Omega-3 Fatty Acids and Oral-Hypoglycemic Drug on Lipid Normalization through Modulation of Hepatic Gene Expression in High Fat Diet with Low Streptozotocin-Induced Diabetic Rats. Nutrients 2020, 12, 3652. [CrossRef]

16. Enani, S.; Bahijri, S.; Malibary, M.; Jambi, H.; Eldakhakhny, B.; Al-Ahmadi, J.; Al Raddadi, R.; Ajabnoor, G.; Boraie, A.; Tuomilehto, J. The Association between Dyslipidemia, Dietary Habits and Other Lifestyle Indicators among Non-Diabetic Attendees of Primary Health Care Centers in Jeddah, Saudi Arabia. Nutrients 2020, 12, 2441. [CrossRef]

17. Tan, L.-J.; Kim, S.-A.; Shin, S. Association between Three Low-Carbohydrate Diet Scores and Lipid Metabolism among Chinese Adults. Nutrients 2020, 12, 1307. [CrossRef]

18. Cicero, A.; Fogacci, F.; Desideri, G.; Grandi, E.; Rizzoli, E.; D’Addato, S.; Borghi, C. Arterial Stiffness, Sugar-Sweetened Beverages and Fruits Intake in a Rural Population Sample: Data from the Brisighella Heart Study. Nutrients 2019, 11, 2674. [CrossRef] 
19. Al-Musharaf, S.; Aljuraiban, G.S.; Danish Hussain, S.; Alnaami, A.M.; Saravanan, P.; Al-Daghri, N. Low Serum Vitamin B12 Levels Are Associated with Adverse Lipid Profiles in Apparently Healthy Young Saudi Women. Nutrients 2020, 12, 2395. [CrossRef]

20. Cicero, A.F.G.; Fogacci, F.; Veronesi, M.; Strocchi, E.; Grandi, E.; Rizzoli, E.; Poli, A.; Marangoni, F.; Borghi, C. A Randomized Placebo-Controlled Clinical Trial to Evaluate the Medium-Term Effects of Oat Fibers on Human Health: The Beta-Glucan Effects on Lipid Profile, Glycemia and inTestinal Health (BELT) Study. Nutrients 2020, 12, 686. [CrossRef]

21. Cicero, A.F.G.; D'Addato, S.; Borghi, C. A Randomized, Double-Blinded, Placebo-Controlled, Clinical Study of the Effects of a Nutraceutical Combination (LEVELIP DUO ${ }^{\circledR}$ ) on LDL Cholesterol Levels and Lipid Pattern in Subjects with Sub-Optimal Blood Cholesterol Levels (NATCOL Study). Nutrients 2020, 12, 3127. [CrossRef] [PubMed]

22. Cicero, A.F.G.; Kennedy, C.; Knežević, T.; Bove, M.; Georges, C.M.G.; Šatrauskienė, A.; Toth, P.P.; Fogacci, F. Efficacy and Safety of Armolipid Plus ${ }^{\circledR}$ : An Updated PRISMA Compliant Systematic Review and Meta-Analysis of Randomized Controlled Clinical Trials. Nutrients 2021, 13, 638. [CrossRef] 